\title{
Neotypification of Protoparmeliopsis garovaglii and molecular evidence of its occurrence in Poland and South America
}

\author{
Katarzyna Szczepańska', Pamela Rodriguez-Flakus², \\ Jacek Urbaniak', Lucyna Śliwa ${ }^{3}$
}

I Department of Botany and Plant Ecology, Wroclaw University of Environmental and Life Sciences, pl. Grunwaldzki 24a, PL-50-363 Wroctaw, Poland 2 Laboratory of Molecular Analyses, W. Szafer Institute of Botany, Polish Academy of Sciences, Lubicz 46, PL-31-512 Kraków, Poland 3 Department of Lichenology, W. Szafer Institute of Botany, Polish Academy of Sciences, Lubicz 46, PL-31-512 Kraków, Poland

Corresponding author: Katarzyna Szczepańska (katarzyna.szczepanska@upwr.edu.pl)

Academic editor: Garima Singh | Received 13 March 2019 | Accepted 25 June 2019 | Published 1 August 2019

Citation: Szczepańska K, Rodriguez-Flakus P, Urbaniak J, Śliwa L (2019) Neotypification of Protoparmeliopsis garovaglii and molecular evidence of its occurrence in Poland and South America. MycoKeys 57: 31-46. https://doi. org/10.3897/mycokeys.57.34501

\begin{abstract}
Protoparmeliopsis garovaglii is a widely distributed placodioid lichen, which develops a distinctly rosette thallus, composed of elongated and strongly inflated to sinuous-plicate lobes. The taxon is characterised by high morphological plasticity and varied composition of secondary metabolites. However, the epithet was never typified. As such, the identity of $P$. garovaglii, in its strict sense, was unknown for a long time. Our phylogenetic ITS rDNA analyses, including newly generated sequences, show that European (Austria, Poland), North American (USA) and South American (Bolivia, Peru) specimens of P. garovaglii are placed in a strongly supported monophyletic clade, sister to $P$. muralis. We provide the first molecular evidence of the occurrence of $P$. garovaglii in South America (Bolivia and Peru) and the second record in Central Europe (Poland) was also provided. Furthermore, we neotypify $P$. garovaglii and it is reported here for the first time from Poland.
\end{abstract}

\section{Keywords}

Geographical distribution, ITS rDNA, lichenised fungi, phylogeny, taxonomy, typification 


\section{Introduction}

The genus, Protoparmeliopsis Choisy, belongs to the large family of lichenised fungi Lecanoraceae. It includes species with a placodioid or umbilicate type of thallus, growing on siliceous rocks or on soil (Zhao et al. 2016). They produce lecanorine apothecia and Lecanora-type asci, specifically containing hyaline, simple ascospores. Their centre of distribution is concentrated in semi-arid regions of the northern Hemisphere. Although well established at present, owing to their treatment by Zhao et al. (2016), the history of the genus taxonomy and nomenclature is very complicated.

The Protoparmeliopsis genus was proposed by Choisy in 1929 with Protoparmeliopsis muralis indicated as a type species. However, the generic concept was not followed and, consequently, the majority of the lecanoroid species with characteristic placodioid thallus morphology were, for decades, included into the Lecanora subg. Placodium sect. Placodium group. This section was proposed by Ryan and Nash (1993) for the Lecanora species characterised by an areolate-squamulose, lobate or subfoliose thallus, usually with a true cortex and loose medulla. Modern insights into the genus taxonomy afforded by molecular studies, however, revealed that thallus morphology in lecanoroid lichens does not reflect phylogenetic relationships. Moreover, the genus, Lecanora sensu lato, as well as subgenus, Placodium, turned out to be highly heterogeneous and polyphyletic (Poelt and Grube 1993; Arup and Grube 1998; Pérez-Ortega et al. 2010; Kondratyuk et al. 2014b; Leavitt et al. 2016). Still, the Protoparmeliopsis genus was not accepted as a separate genus in the family, Lecanoraceae, for a long time, based on the molecular data (Lumbsch and Huhndorf 2007, 2010). Recent studies have identified it as a well-supported, monophyletic clade nested within Lecanora s.l. and it has been subsequently posited to be accepted at the generic level (Kondratyuk et al. 2014b; Miadlikowska et al. 2014; Zhao et al. 2016).

During independent research, concentrated on the biodiversity of saxicolous lichens in Bolivia and Peru, as well as southern Poland, an interesting placodioid representative of Lecanoraceae has been found. Morphology and chemistry of the species suggested that it belongs to the Protoparmeliopsis genus. However, establishing its epithet turned out to be challenging. The scope of our study was to explain the systematic position of the lichen with application of integrated taxonomy tools. The survey revealed that the collection represents $P$. garovaglii and the status of the species is briefly discussed. As the epithet was never typified, a herbarium query was performed and, as a result, the species is neotypified herein.

\section{Material and methods}

\section{Morphology and chemistry}

This study is based on collections from the following herbaria: ASU, KRAM, L, MIN and WRSL, as well as the first author's private material (hb. Szczepańska). The mor- 
phology and anatomy of the specimens were studied with a dissecting and light microscope according to routine techniques. For light microscopy, vertical, free-hand sections of apothecia were cut by a razor blade and mounted in water. Hymenium measurements were made in water and ascospores measurements in $10 \%$ potassium hydroxide $-\mathrm{KOH}(\mathrm{K})$. The structure and conglutination of paraphyses were also studied in K. The solubility of granules in epihymenium was tested with $\mathrm{K}$ and $\mathrm{N}$ (50\% nitric acid). At least 10 measurements of the morphological variables were made for each sample and 20 spores from different specimens were assessed, as well as their minimum and maximum values being calculated.

Chemical examination included colour reactions and thin-layer chromatography (TLC). Spot test reactions of thalli, apothecial margins and discs were made with $\mathrm{K}$, sodium hypochlorite [commercial laundry bleach] (C) and paraphenylenediamine [solution in 95\% ethyl alcohol] (PD). The TLC analyses were undertaken in solvent system A, B' and C using the standardised method of Culberson (1972) and following Orange et al. (2001).

Descriptions of the species are based on our own observations, measurements and TLC analyses made while examining the specimens cited in this paper. All specimens presented in the manuscript as in "Specimens examined" and included in the molecular analysis were studied; however, the morphological description of Protoparmeliopsis garovaglii is primarily based on the proposed neotype specimen. The terminology used in the descriptions of the species is based on Ryan et al. (2004).

\section{DNA extraction, amplification and sequencing}

Genomic DNA was extracted from lichen thalli using the CTab method (Cubero and Crespo 2002). Dried tissues were frozen using liquid nitrogen and disrupted using Mixer Mill MM400 (Retsch; Haan, Germany). The isolated DNA was visualised on $1 \%$ TBE agarose gel. The fungal Internal Transcribed Spacer (ITS) rDNA region, which is a commonly used universal barcode marker in studies of non-lichenised and lichenised fungi, has been used in our study. ITS rDNA regions were amplified using primers ITS1F (Gardes and Bruns 1993) and ITS4 (White et al. 1990). The PCR reaction mix included (in the total volume of $20 \mu \mathrm{l}$ ): $1 \mathrm{U}$ Taq recombinant polymerase (Thermo-Fisher Scientific, USA), $10 X$ Taq Buffer, $1 \mathrm{mM} \mathrm{MgCl}, 0.5 \mu \mathrm{M}$ of each primer, $0.4 \mathrm{mM}$ dNTP and $1 \mu \mathrm{DNA}$ template. The PCR cycle was undertaken with a Veriti Thermal Cycler (Life Technologies; Carlsbad, CA, USA) with the following parameters: $8 \mathrm{~min}$ at $95^{\circ} \mathrm{C}$, followed by 32 cycles: $45 \mathrm{~s}$ at $95^{\circ} \mathrm{C}, 45 \mathrm{~s}$ at $52{ }^{\circ} \mathrm{C}$ (annealing), $1 \mathrm{~min}$ at $72{ }^{\circ} \mathrm{C}$, with a final extension step of $10 \mathrm{~min}$ at $72{ }^{\circ} \mathrm{C}$. Prior to sequencing, PCR products were purified using GeneMATRIX PCR/DNA Clean Up Purification Kit (Eurx; Gdańsk, Poland). Sequencing, post-reaction purification and readings were undertaken by the sequencing service Genomed (Genomed S.A.; Warsaw, Poland), using an ABI 377XL Automated DNA Sequencer (Applied Biosystems; Carlsbad, CA, USA). 


\section{Phylogenetic analysis}

The obtained ITS rDNA sequences were assembled and manually edited using Geneious Pro, version 8.0. (Biomatters Ltd) and we also compared our fragments against the BLAST database in order to avoid potential contamination of other fungi (Altschul et al. 1990). We selected ITS sequences of Protoparmeliopsis garovaglii, $P$. achariana, P. macrocyclos, P. muralis, P. peltata, P. zareii and related genera (Myriolecis, Protoparmelia and Rhizoplaca), newly obtained in this study or downloaded from GenBank. Detailed information regarding sequences including GenBank accession numbers and specimen localities are found in Table 1. Subsequently, the final alignment was performed on the GUIDANCE 2 webserver (Sela et al. 2015) using the MAFFT algorithm (Katoh et al. 2005). The unreliable sites were removed (ca. $90 \%$ of sites remain in the alignment) in order to reduce errors caused by ambiguous sites (Penn et al. 2010). The nucleotide substitution models were separately searched for each subset of the partition of the ITS region (ITS1, 5.8S, ITS2) to find the best-fitting model using the corrected Akaike information criterion (AICc) as an optimality model criterion for a greedy algorithm search, as implemented in PartitionFinder version 1.0.1 (Lanfear et al. 2012).

The phylogenetic construction was generated using the Maximum Likelihood (ML) bootstrap tree with simultaneous heuristic search, as implemented in RaxmlGUI version 0.9 beta 2 (Stamatakis 2006; Silvestro and Michalak 2012) under the GTRGAMMA substitution model and 200 bootstrap re-samples. Bayesian Inference was carried out with Markov Chain Monte Carlo (MCMC) implemented in MrBayes

Table I. The species and specimens studied; newly generated sequences for this study are in bold.

\begin{tabular}{|c|c|c|c|c|c|}
\hline Species & Isolate & Locality & Collector (-s) & Voucher specimens (herbarium) & $\begin{array}{l}\text { GenBank } \\
\text { no. (ITS) }\end{array}$ \\
\hline Myriolecis contractula & $\begin{array}{c}\text { AFTOL-ID } \\
877\end{array}$ & $\begin{array}{c}\text { USA, Washington } \\
\text { country }\end{array}$ & Brodo & Brodo 31501 (DUKE) & HQ650604 \\
\hline \multirow[t]{2}{*}{ Myriolecis dispersa } & & USA, Illinois & Leavitt & Leavitt 12-002 (BRY-C) & KT453733 \\
\hline & & Unitet Kingdom & Hill s.n. & & KT453734 \\
\hline Protoparmeliopsis achariana & & & & U155 & AF070019 \\
\hline \multirow[t]{19}{*}{ Protoparmeliopsis garovaglii } & & Austria & & & AF189718 \\
\hline & 78 & USA, Idaho & Leavitt & Leavitt 078 (BRY-C) & KU934540 \\
\hline & 88 & USA, Idaho & Leavitt & Leavitt 078 (BRY-C) & KU934541 \\
\hline & 89 & USA, Idaho & Leavitt & Leavitt 079 (BRY-C) & KT453728 \\
\hline & 95 & USA, Idaho & Leavitt & Leavitt 095 (BRY-C) & KU934542 \\
\hline & 104 & USA, Idaho & Leavitt & Leavitt 104 (BRY-C) & KU934544 \\
\hline & 105 & USA, Idaho & Leavitt & Leavitt 105 (BRY-C) & KU934545 \\
\hline & 106 & USA, Idaho & Leavitt & Leavitt 106 (BRY-C) & KU934546 \\
\hline & 107 & USA, Idaho & Leavitt & Leavitt 107 (BRY-C) & KU934547 \\
\hline & 108 & USA, Idaho & Leavitt & Leavitt 108 (BRY-C) & KU934548 \\
\hline & 109 & USA, Idaho & Leavitt & Leavitt 109 (BRY-C) & KU934549 \\
\hline & 110 & USA, Idaho & Leavitt & Leavitt 110 (BRY-C) & KU934543 \\
\hline & 116 & USA, Idaho & Leavitt & Leavitt 116 (BRY-C) & KU934550 \\
\hline & 139 & USA, Utah & Leavitt & Leavitt 139 (BRY-C) & KU934551 \\
\hline & 140 & USA, Utah & Leavitt & Leavitt 140 (BRY-C) & KU934535 \\
\hline & 142 & USA, Utah & Leavitt & Leavitt 142 (BRY-C) & KT453729 \\
\hline & 142 & USA, Utah & Leavitt & Leavitt 142 (BRY-C) & KU934536 \\
\hline & 145 & USA, Utah & Leavitt & Leavitt 145 (BRY-C) & KT453727 \\
\hline & 199 & USA, Utah & Leavitt & Leavitt 199 (BRY-C) & KU934537 \\
\hline
\end{tabular}




\begin{tabular}{|c|c|c|c|c|c|}
\hline Species & Isolate & Locality & Collector (-s) & Voucher specimens (herbarium) & $\begin{array}{l}\text { GenBank } \\
\text { no. (ITS) }\end{array}$ \\
\hline Protoparmeliopsis & L21 & Poland & Szczepańska & Szczepańska 1240 (WRSL) & MK084624 \\
\hline \multirow[t]{5}{*}{ garovaglii } & L88 & Bolivia & Flakus & Flakus 17529 (KRAM) & MK084625 \\
\hline & L89 & Bolivia & Flakus & Flakus 21175 (KRAM) & MK084626 \\
\hline & L90 & Bolivia & Flakus & Flakus 21118 (KRAM) & MK084627 \\
\hline & L91 & Peru & Flakus & Flakus 9540 (KRAM) & MK084629 \\
\hline & L92 & Peru & Flakus & Flakus 9603 (KRAM) & MK084628 \\
\hline Protoparmeliopsis macrocyclos & & Sweden & & $\mathrm{U} 273$ & AF159933 \\
\hline \multirow[t]{11}{*}{ Protoparmeliopsis muralis } & & & & M122 & AF070015 \\
\hline & DNA 9890 & Germany, Saxony & Scholz & Scholz $0275697(\mathrm{M})$ & KT818623 \\
\hline & SK 765 & Romania & J.-S. Hur & J.-S. Hur (RO11-130) KOLRI & KP059048 \\
\hline & & Russia & Vondrak & Vondrak 106a (PRA) & KU934559 \\
\hline & & Russia & Vondrak & Vondrak 106b (PRA) & KU934560 \\
\hline & & Russia & Vondrak & Vondrak 9405 (PRA) & KU934556 \\
\hline & & Russia & Vondrak & Vondrak 9417 (PRA) & KU934557 \\
\hline & & Russia & Vondrak & Vondrak 9417 (PRA) & KT453724 \\
\hline & 77 & USA, Utah & Leavitt & Leavitt 077 (BRY-C) & KU934552 \\
\hline & 141 & USA, Utah & Leavitt & Leavitt 141 (BRY-C) & KT453725 \\
\hline & 143 & USA, Utah & Leavitt & Leavitt 143 (BRY-C) & KU934554 \\
\hline \multirow[t]{35}{*}{ Protoparmeliopsis peltata } & & Iran & Sohrabi & MS014622 & KT453723 \\
\hline & & Iran & Sohrabi & MS014620 (personal herbarium) & KU934739 \\
\hline & & Iran & Sohrabi & $\begin{array}{c}\text { MS014621 pelt (personal } \\
\text { herbarium) }\end{array}$ & KU934721 \\
\hline & & Iran & Sohrabi & MS014623 (personal herbarium) & KU934722 \\
\hline & & Iran & Sohrabi & $\begin{array}{c}\text { MS014624pelt (personal } \\
\text { herbarium) }\end{array}$ & KU934723 \\
\hline & & Iran & Sohrabi & MS014630 (personal herbarium) & KU934731 \\
\hline & & Iran & Sohrabi & MS014637 (personal herbarium) & KU934732 \\
\hline & & Iran & Sohrabi & MS014638 (personal herbarium) & KU934733 \\
\hline & & Kazakhstan & & Kaz 12921c & KU934745 \\
\hline & & Kazakhstan & & Kaz 13085pelt & KU934746 \\
\hline & & Kazakhstan & & Kaz 12943 & KU934747 \\
\hline & & Kazakhstan & & Kaz 12948 & KU934748 \\
\hline & & Kazakhstan & & Kaz 13082 & KU934749 \\
\hline & & Kyrgyzstan & $\begin{array}{l}\text { ?Lommi, } \\
\text { Sampsa }\end{array}$ & H920340 & KU934720 \\
\hline & & Kyrgyzstan & & H9203329 & KU934719 \\
\hline & & Kyrgyzstan & & H9203118 & KU934735 \\
\hline & & Kyrgyzstan & & H9203304 & KU934736 \\
\hline & & Kyrgyzstan & & H9203334 & KU934737 \\
\hline & & Kyrgyzstan & & H9203194 & KU934738 \\
\hline & & Russia & Vondrak & Vondrak 9987 (PRA) & KU934725 \\
\hline & & Russia & Vondrak & Vondrak 9997 (PRA) & KU934726 \\
\hline & & Russia & Vondrak & Vondrak 10016 (PRA) & KU934727 \\
\hline & & Russia & Vondrak & Vondrak 10022 (PRA) & KU934728 \\
\hline & & Russia & Vondrak & Vondrak 10041 (PRA) & KU934729 \\
\hline & & Russia & Vondrak & Vondrak 10130 (PRA) & KU934730 \\
\hline & & Russia & Vondrak & Vondrak 9423 (PRA) & KU934740 \\
\hline & & Russia & Vondrak & Vondrak V127 (PRA) & KU934751 \\
\hline & & Russia & AsLap & 951 & KU934742 \\
\hline & & Russia & AitLap & 876 & KU934744 \\
\hline & & Russia & Sar & 937 & KU934743 \\
\hline & & Turkey & Vondrak & Vondrak 9783 (PRA) & KU934724 \\
\hline & & USA & Leavitt & Leavitt 601 (BRY-C) & KU934734 \\
\hline & & USA & Leavitt & Leavitt 663 (BRY-C) & KU934741 \\
\hline & U198 & USA, Arizona & & cf. ASU & $\mathrm{AF} 159925$ \\
\hline & & USA, Utah & & & KT453722 \\
\hline \multirow[t]{2}{*}{ Protoparmeliopsis zareii } & 480 & Iran & B. Zarei-Darki & Zarei-Darki 1111 (SK) & KP059049 \\
\hline & 480 & Iran & B. Zarei-Darki & Zarei-Darki 1111 (SK) & KP059049 \\
\hline
\end{tabular}


v3.2.3 (Ronquist et al. 2011). MrBayes was set to three independent parallel runs, each with four incrementally heated chains started, the run length was settled to $40 \mathrm{M}$ generations and, to infer convergence, the average standard deviation of the split frequencies was printed every $1000^{\text {th }}$ generation, discarding the first $50 \%$ of the trees sampled as a burn-in fraction. The analyses were stopped after $1 \mathrm{M}$ generations when the standard deviation had dropped below 0.01 . The resulting phylogenetic trees were visualised in Figtree software (Rambaut 2014).

\section{Results}

\section{Phylogeny}

A total of 77 sequences were analysed in this study. The final alignment matrix contained eight OTUs and 545 unambiguously aligned nucleotides positions. The phylogeny shows highly supported clades [bootstrap support $(\mathrm{BS})=75 \%$, posterior probability $(\mathrm{PP})=1$ ] inferred from a single locus phylogeny, clearly delimiting the Lecanoraceae as separate from Myriolecis (outgroup) (Fig. 1). P. garovaglii forms a monophyletic clade highly supported (BS $=95 \%, \mathrm{PP}=1)$ within Protoparmeliopsis. The newly generated sequence from Poland is placed in a monophyletic clade $[\mathrm{BS}=100 \%, \mathrm{PP}=1$ ] together with the Austrian sequence. South American (Bolivian and Peru; for the first time molecularly confirmed in this study) and USA populations are placed in different clades but lack statistical support.

\section{Taxonomy}

Protoparmeliopsis garovaglii (Körb.) Arup, Zhao Xin \& Lumbsch; Fungal Diversity 78: 301 (2016) [2015].

Mycobank: 387928

Figs $2 \mathrm{a}-\mathrm{b}$

Basionym. Placodium garovaglii Körb., Parerga Lichenol. (Breslau) 1:54 (1859) 三 Squamaria garovaglii (Körb.) Anzi, Cat. Lich. Sondr. 46 (1860) E Lecanora garovaglii (Körb.) Zahlbr., Ann. Naturhist. Hofmus. 15:208 (1900) E Placolecanora garovaglii (Körb.) Räsänen, Hedwigia 81:230 (1944).

Type. Hungary. Szent-György-hegy Mt, 'Ad saxa basaltica montis "Szentgyörgyhegy” prope pagum Kisapáti, comit. Zala. Altit. ca. 400 m. s. m. Mens. Jun. 1920, G.Timkó' [Flora Hungarici exsiccata 617, as Lecanora garovaglii] (neotype: WRSL5777, designated here).

Description. Thallus lichenised, placodioid, thick, usually distinctly circular, up to $12 \mathrm{~cm}$ diam., not very closely attached to the substrate, prothallus not present. Marginal lobes elongated, distinctly convex, swollen, sinuous, smooth $0.4-1.8 \mathrm{~mm}$ wide and 3-10 mm long, broadened and rounded at the ends (Figs. 2c-d). Thallus centre 


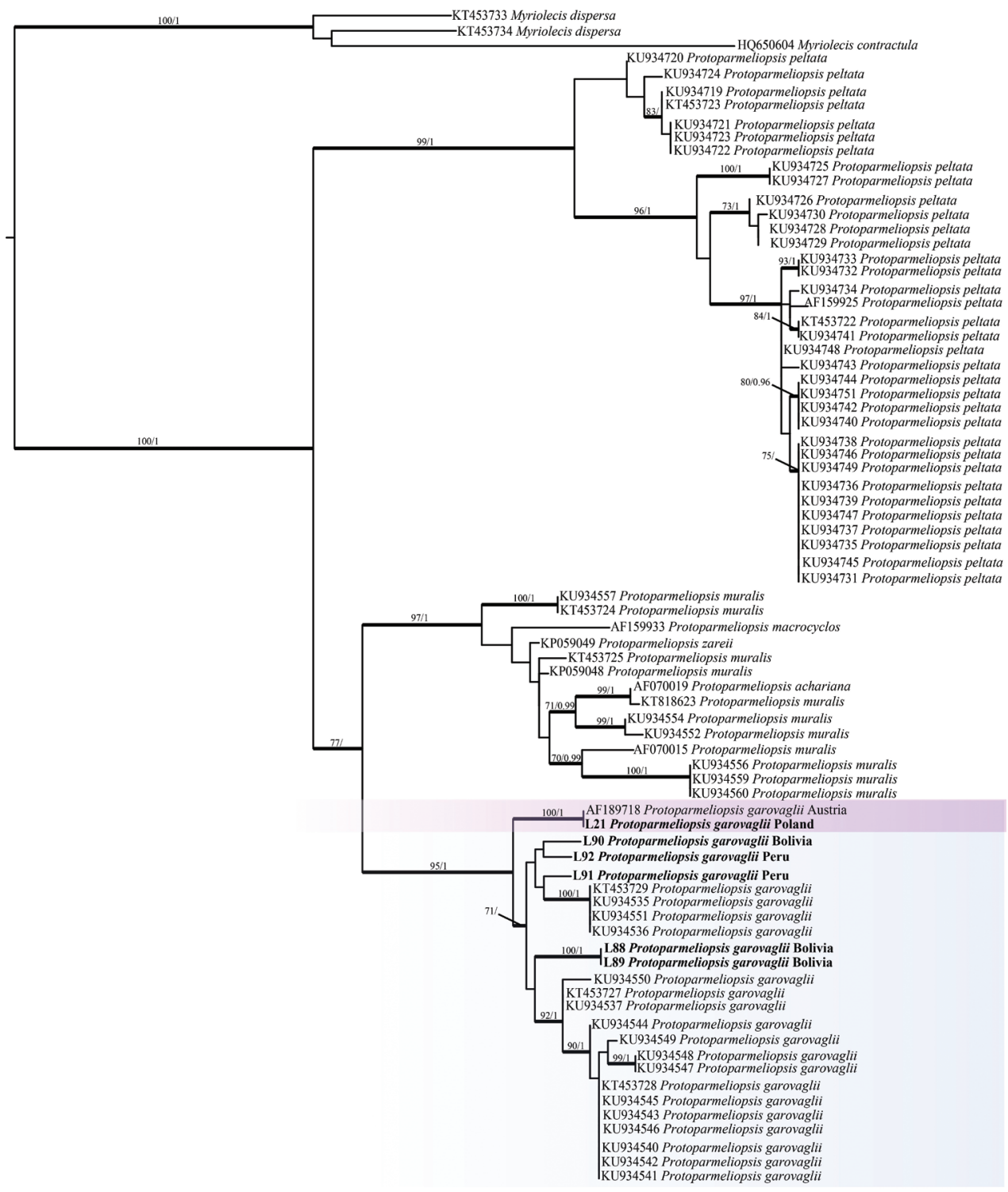

Figure I. Bayesian Inference of the phylogenetic relationship within Protoparmeliopsis species, based on ITS rDNA sequences. High bootstrap support values are shown above thickened branches and bold numbers representing clades ( $\mathrm{ML}-\mathrm{BP} \geq 70 \%$, Bayesian analysis $-\mathrm{PP} \geq 0.9)$. Highlighted squares represent $P$. garovaglii populations in Europe, South and North America. Parmeliaceae species were selected as the outgroup.

more or less areolate. Areoles convex, irregular, overlapping, 0.25-1.0 mm diam. Upper surface mat, pale yellowish-green to greyish-green, tending to be darker in the central part of the thallus, sometimes shining and darker also at the edges of the marginal lobes. Lower surface pale brown. Medulla white, in older lobes distinctly hollow in 

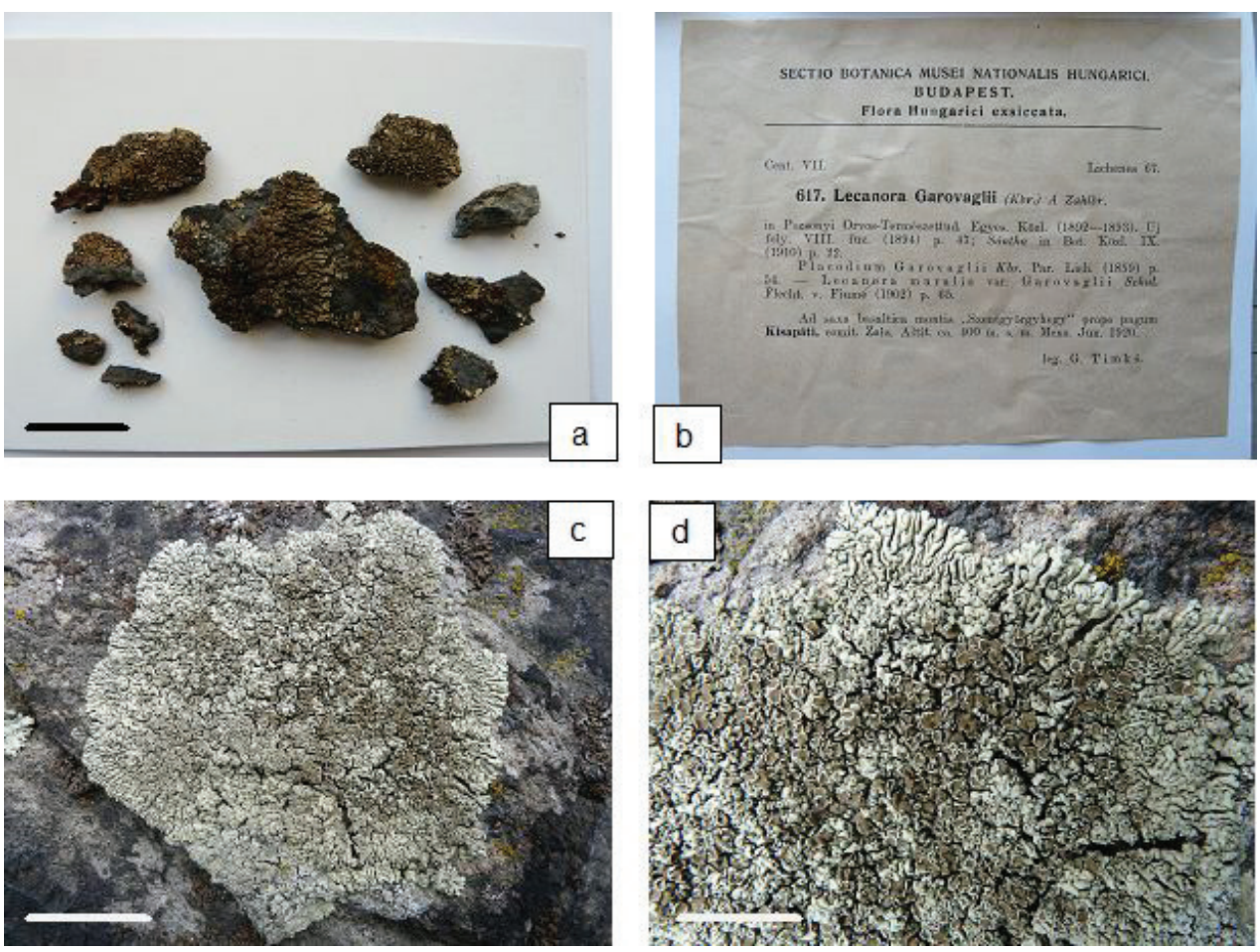

Figure 2. a, b Neotype for Protoparmeliopsis garovaglii designated in WRSL herbarium c, d Thallus of Protoparmeliopsis garovaglii in natural habitat. Scales: $2 \mathrm{~cm}(\mathbf{a}) ; 4 \mathrm{~cm}(\mathbf{c}) ; 2 \mathrm{~cm}(\mathbf{d})$.

the middle part. Apothecia sessile to constricted at base, dispersed to clustered towards thallus centre, $0.5-2.0 \mathrm{~mm}$ diam., circular, older angular, proper margin persistent, paler or concolorous with thallus, matte, slightly radially cracked, flexuose in older and disappearing in mature apothecia. Disc pale brown to yellowish-brown, becoming darker in the centre of thallus, epruinose, flat. Hymenium colourless, 50-60 $\mu \mathrm{m}$ high, hypothecium colourless, epihymenium orange-brown with small granules soluble in $\mathrm{K}$ and insoluble in N. Asci clavate, eight-spored. Paraphyses simple or weakly branched with swollen apices. Ascospores hyaline, simple, ellipsoid to oblong-elipsoid, 10-12 $\times$ 6-7 $\mu \mathrm{m}$. Pycnidia not seen.

Chemistry. thallus $\mathrm{K}+$ pale yellow, $\mathrm{C}-, \mathrm{KC}+$ yellow, $\mathrm{P}-$; medulla $\mathrm{K}+$ pale yellow, $\mathrm{C}-, \mathrm{KC}+$ yellow, $\mathrm{P}-$. Secondary metabolites detected by TLC: \pm isousnic, +usnic and \pm placodiolic acids (cortex); +zeorin and \pm unidentified terpenoides (medulla).

Distribution. the species is widely distributed in the world. It occurs in Europe, Asia, Africa (Morocco; Egea 1996), North America (Canada; Freebury 2014 and USA; Ryan et al. 2004) and South America (Feuerer et al. 1998; Feuerer and Sipman 2005). In Asia, it has been noted in Afghanistan (Poelt and Wirth 1968), India (Upreti and Chatterjee 1998; Singh and Sinha 2010), Iran (Sohrabi et al. 2010), Mongolia (Schubert and Klement 1971), Pakistan (Poelt 1961), Russia (Vondráková and Vondrák 2015), Tajikistan (Kudratov and Mayrhofer 2002) and Turkey (Halici and Candan 2007). In Europe, its records are derived so far from Armenia (Gasparyan et al. 2016), 
Austria (Hafellner and Türk 2001), the Czech Republic (Vězda and Liška 1999), Germany (Wirth 1995), Greece (Grube et al. 2001), Italy (Nimis 2016), Netherlands (Aptroot 2011), Portugal and Spain (Llimona and Hladun 2001), as well as Ukraine (Kondratyuk et al. 1996). Here, the species is reported for the first time from Poland.

Ecology. Protoparmeliopsis garovaglii is widespread, occurring mostly in dry and warm Mediterranean to mountain areas, foothills and submontane sites (Ryan et al. 2004). It prefers slightly calcareous or basic silicate rocks (limestone, basalt, rhyolite, schist, pumice, volcanic ash, sandstone) and usually occupies sunny habitats, especially steep surfaces (Wirth 1995; Ryan et al. 2004). However, it is noteworthy that, on its northernmost locality in the Netherlands, the species was recorded on a tombstone (Aptroot 2011). In Poland, it was found in mountain areas with outcrops of basalt rocks in the form of a volcanic chimney, surrounded by granite casing. It occupied a lit, warm and dry place on the horizontal surface of the basalt rock with a southern exposure and was accompanied by other lichens such as Acarospora fuscata, Candelariella coralliza, Protoparmeliopsis muralis, Lecanora rupicola and Rhizocarpon geographicum. During the present study in Bolivia and Peru, P. garovaglii was recorded in high Andean openvegetative regions and in open semi-desert montane areas.

Exiccates examined. Pišut, Lichenes Slovakiae exsiccati 36, as Lecanora garovaglii (KRAM); Suza, Lichenes Bohemoslovakiae exiccati 233, as Lecanora garovaglii (KRAM); Weber, Lichenes exsiccati 118, as Lecanora garovaglii (KRAM).

Specimens examined. Poland. Przedgórze Sudeckie foreland: Wzgórza Strzegomskie hills, Góra Świętego Jerzego Mt, 5058'25"N, 16²0'10"E, on basalt rocks, $354 \mathrm{~m}$ alt., 4 Oct. 2013, K.Szczepańska 1240 (WRSL). Bolivia. Dept. La Paz, Prov. Bautista Saavedra: Anmin Apolobamba, near Taypi Cañuma village, 1503'20"S, 6909'07"W, 4506 m alt., 5 July 2010, A.Flakus 17529 \& P.Rodriguez-Flakus (KRAM, LPB); on the road from Apolo to Charazani villages $(162 \mathrm{~km})$, la Cruz Charazani-Pelechuco, $15^{\circ} 15^{\prime} 00^{\prime \prime S}, 69^{\circ} 02^{\prime} 51^{\prime \prime W}, 4545 \mathrm{~m}$ alt., 19 May 2011, A.Flakus 21118, 21175, 21176 \& O.Plata (KRAM, LPB). Peru. Cañon del Colca, Dept. Arequipa, Prov. Caylloma: near Cabanaconde village, 15³7'56"S, 7157'49"W, 3462 m alt., 4 July 2006,

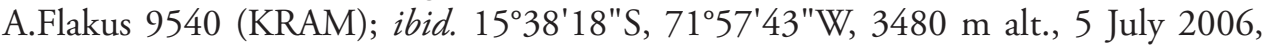
A.Flakus 9603 (KRAM).

Additional specimens examined. Austria. Lower Austria: sunny slate rocks near Krems on the Danube River, 250 m alt., 3 Jan. 1897, Baumgarten (L). USA. Arizona. Coconino Co.: Grand Canyon National Forest, top of Hermit Trail, pinyon-juniper woodland, on limestone, 1950 m alt., 11 July 1994, T.H.Nash III 35474 (ASU); ibid., South Kaibab Trail, on sandstone, 1950 m alt., 29 June 1991, M.Boykin 2053 (ASU); Greenlee Co.: Apache National Forest, Juan Miller Canyon camp-ground, along the Blue River, ponderosa pine forest with riparian sp., on acid rock, $1740 \mathrm{~m}$ alt., 6 June 1998, T.H.Nash III 41809 (ASU); Maricopa Co.: Crater Range, along AZ 85, 42 $\mathrm{km} \mathrm{S}$ of Gila Bend Sonoran Desert, on granite, 425 m alt., 27 Feb. 1998, T.H.Nash III 40608 (ASU); Santa Cruz Co.: Coronado National Forest, hillsides to S of Pena Blanca Lake (ca. $15 \mathrm{~km}$ WNW of Nogales) and just S of Ruby-Nogales Rd., oak woodland steep slope with rhyolite, on rhyolite, $1200 \mathrm{~m}$ alt., 2 June 1998, T.H.Nash III 41656 (ASU). Idaho. Twin Falls Co.: E side of U.S. Hwy 30, $6.8 \mathrm{~km} \mathrm{~S}$ of Bills, on 
basalt, 915 m alt., 11 Sept. 1998, B.D.Ryan 32953 (ASU). Nevada. Churchill Co.: US Hwy 50, N end of Desatoga Mountains, $84 \mathrm{~m}$ E of Fallon, $1830 \mathrm{~m}$ alt., July 1984, B.D.Ryan 11554 (MIN). North Dakota. Billings Co.: Theodore Rooselvelt Nat. Park, S. Unit One mile $S$ of Paddock Creek along park road, on ridge $E$ of road on scoria rock, 2500 ft. alt., 25 July 1982, C. Wetmore 45128 (MIN). Montana. Park Co.: Yellowstone National Park, Grazing enclosure 1 mile W of Gardiner at northern edge of park, open grassland on knoll with sagebrush and rock outcrop, $5300 \mathrm{ft}$. alt., 21 July 1998, C.Wetmore 80972 (MIN).

\section{Discussion}

Protoparmeliopsis garovaglii was traditionally characterised by its typically elongate and strongly inflated-plicate lobes of the thalli. For most details, the species was studied by Ryan and Nash (1993), who treated it as a single frequent widespread and extremely variable taxon - Lecanora garovaglii s.l., including L. cascadensis H. Magn., L. nevadensis $\mathrm{H}$. Magn. and L. peruviana (Müll. Arg.) Zahlbr. By examining hundreds of specimens, the authors were deeply involved in discussions about the species' variety concerning colour of apothecial discs and associated epihymenial features. They finally concluded that the set of mentioned phenotypic traits is often not clearly expressed and does not exhibit clear correlations with other characters, such as secondary chemistry. Moreover, both disc colour and cortical chemistry correlate with habitat and distribution, respectively, rather than directly with each other. According to us, this serves as evidence of possible phenotypic plasticity, not taxon speciation. The cortical chemistry variation throughout the geographical range of $L$. garovaglii with three cortical substances (isousnic, usnic and placodiolic acids) in different combinations is a separate, interesting problem, discussed in the paper by Ryan and Nash (1993) and ending with the statement that the name cannot be unambiguously assigned to any of the known chemotypes as it is not typified. In this situation, the authors referred to the only specimen under the name, Placodium garovaglii, available at that time in the Körber "Typenherbar" in L, originating from "Vel Furva" (Valfurva city, Italy) and containing isousnic and usnic acids in the cortex. However, Körber's collection is kept in the Leiden Herbarium as two different parts. Specimens from the first (Hauptsammlung) are labelled as "Koerber Stammherbar" and those from the second (Typensammlung) as "Koerber Typenherbar" (Liška 2013). It is not clear if Ryan and Nash (1993) searched for original material in both collections or only in the "Typenherbar".

During our study, we tried to trace the original collection of the species. Type citation in the protologue is: 'An basaltigem Gestein "in monte supra Varzi” von Garovaglio gesammelt (Herb. Heufl.)' [Italy, Prov. Pavia, Region of Lombardy, the mountain above Varzi city, on basalt rock, leg. Garovaglio] (Körber, 1859-1865). Heufler's herbarium was sold after his death and currently the final destination of the samples is unknown. We started our enquiries at IBF where Haufler deposited much of his herbarium material during his lifetime. This did not bring any resolution as our double request did not elicit a response. We also requested the specimens of $P$. garovaglii 
from $\mathrm{L}$ herbarium. Subsequent to the request, we received the historical collection of $P$. garovaglii from the locality: Lower Austria, sunny slate rocks near Krems on the Danube River, alt. 250 m, 3 Jan. 1897, leg. Baumgarten. Obviously, the species cannot be lectotypified, as there is only one locality cited in the protologue and the original collection of the species from locus classicus could not be located at any herbaria and may have been lost. For name typification, we considered the collection available at L, however, its lowland origin and cortical chemistry (usnic and placodiolic acids) indicate that it would not be the best choice. We have also made a request at WRSL herbarium knowing that some small part of Körber's collection is also located there. However, none of Körber's specimens representing P. garovaglii was available. The most appropriate material for the neotype of the historical collections seen by us is apparently the exsiccate from WRSL, collected in the mountain area of Hungary and it was designated there. This specimen is well preserved, was collected from the basalt rock, has typical morphology suitable to the description given in the protologue and the following cortical chemistry: isousnic, usnic and placodiolic acids (the most frequent chemotype in Europe, according to Ryan and Nash (1993)).

The species most closely related and likely to be confused with $P$. garovaglii is $P$. muralis. In contrast to $P$. garovaglii, the thallus of $P$. muralis is smaller and much more strongly attached to the substrate. Furthermore, thallus lobes of the latter species are distinctly shorter, flattened and thinner and not swollen or sinuous-plicate as they are in the case of $P$. garovaglii. Both species can also be distinguished by their chemistry. Protoparmeliopsis muralis contains usnic acid and zeorin but also atranorin, leucotylin, murolic and psoromic acids; the latter are not produced by $P$. garovaglii (Wirth 1995; Ryan et al. 2004; Edwards et al. 2009). To some extent, P. garovaglii may also be mistaken with Rhizoplaca subdiscrepans (Nyl.) R. Sant., especially as both species have similar colour of the upper surface of the thallus and prefer similar, warm and dry habitats (Wirth 1995; Hafellner and Türk 2001). However, in contrast to $P$. garovaglii, the thallus of $R$. subdiscrepans is usually verrucose-squamulose, polyphyllous, without distinct lobes at the margin and pruinose apothecial discs (Ryan 2001). Both species also have similar cortical chemistry with isousnic, usnic and placodiolic acids in the upper cortex, but $P$. garovaglii additionally contains zeorin in the medulla.

Protoparmeliopsis garovaglii was included in previous phylogenetic frameworks focused on European, North American and Asian populations (Arup and Grube 1998, 2000; Leavitt et al. 2016; Kondratyuk et al. 2014a, b). In this study, we included new sequences from South America and they are placed in a single, highly supported, species-level lineage $(\mathrm{BS}=100 \%, \mathrm{PP}=1)$. There is a geographical differentiation tendency based on our molecular output. The Polish specimen is placed in a monophyletic clade with a highly supported group $(\mathrm{BS}=100 \%, \mathrm{PP}=1)$ together with the Austrian sequence. Bolivian, Peruvian and North American populations are placed in different clades but, in most cases, the internal node lacks statistical support. This tendency may follow a population geographical disjunction of different organisms, including lichens, in which the morphological and chemical characters are highly variable in a single species, making a real challenge for species delimitation and, in most cases, these species are treated as a 'complex'. In the case of lichenised fungi, some previous extensive 
studies on molecular population or/and phylogeography analyses on species recognition boundaries, such as Usnea perpusilla (Wirtz et al. 2008), Leptogium furfuraceum (Otálora et al. 2010) Xanthoparmelia pulla (Amo de Paz et al. 2012), were performed.

In our study, we analysed differences in morphology, anatomy and chemistry of specimens representing different clades. European material is characterised by a pale green colour of the thallus with elongated, distinctly convex and swollen marginal lobes, which is not very closely attached to the substrate. The apothecial discs are epruinose, bright to dark brown in colour. Within material originating from Bolivia and Peru, we found very similar morphology of the apothecia and thallus, however the thallus colour of Bolivian specimens is more pale yellow than green. In North American, the thallus in many cases is smaller and more closely attached to the substrate, with flat, shorter and narrower marginal lobes $(0.3-1.2 \mathrm{~mm}$ wide and 2-6 $\mathrm{mm}$ long) and is additionally pruinose at the ends. The colour of the discs is usually brown but also yellow-green or yellow-orange, when the upper surface of the thallus has more orange tint. No significant differences were found in the colour or height of the hymenium and epihymenium, nor the paraphyses or shape and size of spores in the specimens representing different clades. Furthermore, we have not found any correlation between secondary chemistry of the thallus and species distribution. Both specimens from Europe, South and North America (Bolivia, Peru and USA) contain zeorin and usnic acids as solid components, when isousnic and placodiolic acids, as well as unidentified terpenoides may be present or absent; however, no sample from South America contained isousnic acid.

Based on these observations, we may confirm great phenotypic variation of specimens representing P. garovaglii s.l., also observed by Ryan and Nash (1993). However, we cannot unambiguously correlate perceivable morphotypes with appropriate clades. In particular, morphological differentiation may also greatly reflect responses of individuals to diversity of habitat conditions. Moreover, any far-reaching conclusions must be based on a larger sampling size and should be statistically supported.

We do not claim to assign any taxonomic resolutions concerning P. garovaglii s.l. until further molecular population studies provide evidence for species delimitation within the species-complex. The intention of the current study was to genetically support the identification of $P$. garovaglii in collections from areas of research interest to the authors. As a result, molecular evidence of the species occurrences in Poland and South America (Bolivia and Peru) was supplied. Typification of the epithet $P$. garovaglii, via this work, should be useful for further circumscription of related taxa.

\section{Acknowledgements}

The curators of ASU, L, MIN and WRSL are gratefully acknowledged for loan of specimens. PRF is greatly indebted to the Director of Herbario Nacional de Bolivia, Instituto de Ecología, Universidad Mayor de San Andrés, La Paz, for generous cooperation. We are grateful to Adam Flakus (Kraków) and Martin Kukwa (Gdańsk) for 
helpful assistance with TLC analyses. This work was supported by statutory funds of Wroclaw University of Environmental and Life Sciences and the W. Szafer Institute of Botany, Polish Academy of Sciences as well as by National Science Centre, Poland, project 2016/21/B/NZ8/02463.

\section{References}

Altschul SF, Gish W, Miller W, Myers EW, Lipman DJ (1990) Basic local alignment search tool. Journal of Molecular Biology 215: 403-410. https://doi.org/10.1016/S00222836(05)80360-2

Amo de Paz G, Cubas P, Crespo A, Elix JA, Lumbsch HT (2012) Transoceanic dispersal and subsequent diversification on separate continents shaped diversity of the Xanthoparmelia pulla group (Ascomycota). PLoS ONE 7(6): e39683. https://doi.org/10.1371/journal. pone. 0039683

Aptroot A (2011) De Warme schotelkorst (Lecanora garovaglii): een submediterraan korstmos nieuw voor Nederland. Buxbaumiella 89: 46-48.

Arup U, Grube M (1998) Molecular systematics of Lecanora subgenus Placodium. Lichenologist 30: 415-425. https://doi.org/10.1006/lich.1998.0149

Arup U, Grube M (2000) Is Rhizoplaca (Lecanorales, lichenized Ascomycota) a monophyletic genus? Canadian Journal of Botany 78: 318-327. https://doi.org/10.1139/b00-006

Choisy M (1929) Genres nouveaux pour la lichénologie dans le groupe des Lécanoracées. Bulletin de la societe botanique de France 76: 521-527. https://doi.org/10.1080/00378941. 1929.10837179

Cubero OF, Crespo A (2002) Isolation of nucleic acids from lichens. In: Kranner IC, Beckett RP, Varma AK (Eds) Protocols in Lichenology. Springer Lab Manuals. Springer, Berlin, Heidelberg, 381-391. https://doi.org/10.1007/978-3-642-56359-1_23

Culberson CF (1972) Improved conditions and new data for identification of lichen products by standardized thin-layer chromatographic method. Journal of Chromatography 72 : 113-125. https://doi.org/10.1016/0021-9673(72)80013-X

Edwards B, Aptroot A, Hawksworth DL, James PW (2009) Lecanora Ach. in Luyken (1809). In: Smith CW, Aptroot A, Coppins BJ, Fletcher A, Gilbert OL, James PW, Wolseley PA (Eds) The Lichens of Great Britain and Ireland. British Lichen Society, London, $465-502$.

Egea JM (1996) Catalogue of lichenized and lichenicolous fungi of Morocco. Bocconea 6: 19-114.

Feuerer T, Sipman HJM (2005) Additions to the lichenized and lichenicolous fungi of Bolivia. Herzogia 18: 139-144.

Feuerer T, Ahti T, Vitikainen O (1998) Lichenological investigations in Bolivia. In: Marcelli MP, Seaward MRD (Eds) Lichenology in Latin America: history, current knowledge and applications. CETESB, São Paulo, 71-86.

Freebury CE (2014) Lichens and lichenicolous fungi of Grasslands National Park (Saskatchewan, Canada). Opuscula Philolichenum 13: 102-121. 
Gardes M, Bruns TD (1993) ITS primers with enhanced specificity for basidiomycetes-application to the identification of mycorrhizae and rusts. Molecular Ecology 2: 113-118. https:// doi.org/10.1111/j.1365-294X.1993.tb00005.x

Gasparyan A, Aptroot A, Burgaz AR, Otte V, Zakeri Z, Rico VJ, Arauja E, Crespo A, Divakar PK, Lumbsch HT (2016) Additions to the lichenized and lichenicolous mycobiota of Armenia. Herzogia 29: 692-705. https://doi.org/10.13158/heia.29.2.2016.692

Grube M, Lindblom L, Mayrhofer H (2001) Contributions to the lichen flora of Crete: A compilation of references and some new records. Studia Geobotanica 20: 41-59.

Hafellner J, Türk R (2001) Die liechenisierten Pilze Österreichs - eine Checkliste der bisher nachgewiesenen Arten mit Verbreitungsangaben. Stapfia 76: 3-167.

Halici MG, Candan M (2007) Notes on some lichenicolous fungi species from Turkey. Turkish Journal of Botany 31: 353-356. https://doi.org/10.3906/bot-0811-1

Katoh K, Kuma K, Toh H, Miyata T (2005) MAFFT version 5: improvement in accuracy of multiple sequence alignment. Nucleic Acids Research 33: 511-518. https://doi. org/10.1093/nar/gki198

Körber GW (1859-1865) Parerga Lichenologica. Ergänzungen zum Systema Lichenum Germaniae. E. Trewendt, Breslau, 1-501. https://doi.org/10.5962/bhl.title.87905

Kondratyuk S, Navrotskaya I, Khodosovtsev A, Solonina O (1996) Checklist of Ukrainian lichens. Bocconea 6: 217-294.

Kondratyuk S, Jeong MH, Galanina IA, Yakovchenko LS, Yatsyna AP, Hur JS (2014a) Molecular phylogeny of placodioid lichen-forming fungi reveal a new genus, Sedelnikovaea. Mycotaxon 129: 269-282. https://doi.org/10.5248/129.269

Kondratyuk S, Kim J, Kondratiuk AS, Jeong M, Jang S, Pirogov MV, Hur J (2014b) First data on molecular phylogeny of the genus Protoparmeliopsis M. Choisy (Lecanoraceae, Ascomycota). Modern Phytomorphology 5: 63-68.

Kudratov I, Mayrhofer H (2002) Catalogue of the lichenized and lichenicolous fungi of Tajikistan. Herzogia 15: 91-128.

Lanfear R, Calcott B, Ho SYW, Guidon S (2012) PartitionFinder: combined selection of partitioning schemes and substitution models for phylogenetic analyses. Molecular Biology and Evolution 29: 1695-1701. https://doi.org/10.1093/molbev/mss020

Leavitt SD, Kraichak E, Vondrak J, Nelsen MP, Sohrabi M, Pérez-Ortega S, St Clair LL, Lumbsch HT (2016) Cryptic diversity and symbiont interactions in rock-posy lichens. Molecular Phylogenetics and Evolution 99: 261-274. https://doi.org/10.1016/j. ympev.2016.03.030

Liška J (2013) The significance of Körber's "Typenherbar”, with an explanation of the locality abbreviations on his labels. Lichenologist 45: 25-33. https://doi.org/10.1017/ S0024282912000552

Llimona X, Hladun NL (2001) Checklist of the lichens and lichenicolous fungi of the Iberian Peninsula and Balearic Islands. Bocconea 14: 1-581.

Lumbsch HT, Huhndorf SH (2007) Outline of Ascomycota. Myconet 13: 1-58.

Lumbsch HT, Huhndorf SH (2010) Myconet. Volume 14. Part One. Outline of Ascomycota 2009. Fieldiana Life and Earth Sciences 1: 1-42. https://doi.org/10.3158/1557.1 
Miadlikowska J, Frank Kauff F, Högnabba F, Oliver JC, Molnár K, Fraker E, Gaya E, Hafellner J, Hofstetter V, Cécile Gueidan C, Otálora MAG, Hodkinson B, Kukwa M, Lücking R, Björk C, Sipman HJM, Burgaz AR, Thell A, Passo A, Myllys L, Goward T, FernándezBrime S, Hestmark G, Lendemer J, Lumbsch HT, Schmull M, Schoch CL, Sérusiaux E, Maddison DR, Arnold AE, Lutzoni F, Stenroos S (2014) A multigene phylogenetic synthesis for the class Lecanoromycetes (Ascomycota): 1307 fungi representing 1139 infrageneric taxa, 317 genera and 66 families. Molecular Phylogenetics and Evolution 79: 132-168. https://doi.org/10.1016/j.ympev.2014.04.003

Nimis PL (2016) The Lichens of Italy. A Second Annotated Catalogue. EUT Edizioni Università di Trieste, Trieste, $740 \mathrm{pp}$.

Orange A, James PW, White FJ (2001) Microchemical methods for the identification of lichens. British Lichen Society, London, $91 \mathrm{pp}$.

Otálora MAG, Martínez I, Aragón G, Molina MC (2010) Phylogeography and divergence date estimates of a lichen species complex with a disjunct distribution pattern. American Journal of Botany 97: 216-23. https://doi.org/10.3732/ajb.0900064

Penn O, Privman E, Landan G, Graur D, Pupko T (2010) An alignment confidence score capturing robustness to guide-tree uncertainty. Molecular Biology and Evolution 27: 17591767. https://doi.org/10.1093/molbev/msq066

Pérez-Ortega S, Spribille T, Palice Z, Elix JA, Printzen C (2010) A molecular phylogeny of the Lecanora varia group, including a new species from western North America. Mycological Progress 9: 523-535. https://doi.org/10.1007/s11557-010-0660-y

Poelt J (1961) Flechten auf dem NW-Karokaram im Rahmen der Deutschen Karakoram-Expedition 1959 von F. Lobbichler und Dr. J. Schneider gesammelt. Mitteilungen der Botanischen Staatssammlung München 4: 83-94.

Poelt J, Grube M (1993) Beiträge zur Kenntnis der Flechtenflora des Himalaya VIII. -Lecanora subgen. Placodium. Nova Hedwigia 57: 305-352.

Poelt J, Wirth V (1968) Flechten aus dem nordbstlichen Afghanistan, gesammelt von H. Roemer im Rahmen der Deutschen Wakhan-Expedition 1964. Mitt. Bot. Staatssammlung München. 7: 219-261.

Rambaut A (2014) Figtree v.1.4.2. Retrieved from http://tree.bio.ed.ac.uk/software/figtree/.

Ronquist F, Teslenko M, van der Mark P, Ayres D, Darling A, Höhna S, Larget B, Liu L, Suchard MA, Huelsenbeck JP (2011) MrBayes 3.2: efficient Bayesian phylogenetic inference and model choice across a large model space. Systematic Biology 61: 539-542. https://doi.org/10.1093/sysbio/sys029

Ryan BD (2001) Rhizoplaca. In: Nash III TH, Ryan BD, Gries C, Bungartz F (Eds) Lichen Flora of the Greater Sonoran Desert Region, Vol. 1. Lichens Unlimited, Tempe, 442-448. Ryan BD, Nash III TH (1993) Lecanora Section Placodium (Lichenized Ascomycotina) in North America: New Taxa in the L. garovaglii Group. Bryologist 96: 288-298. https://doi. org/10.2307/3243856

Ryan BD, Lumbsch HT, Messuti MI, Printzen C, Śliwa L, Nash III TH (2004) Lecanora. In: Nash III TH, Ryan BD, Gries C, Bungartz F (Eds) Lichen Flora of the Greater Sonoran Desert Region, Vol. 2. Lichens Unlimited, Tempe, 176-286. 
Schubert R, Klement O (1971) Beitrag zur Flechtenflora der Mongolischen Volksrepublik. Feddes Repertorium 82: 187-262. https://doi.org/10.1002/fedr.19710820302

Sela I, Ashkenazy H, Katoh K, Pupko T (2015) GUIDANCE2: accurate detection of unreliable alignment regions accounting for the uncertainty of multiple parameters. Nucleic Acids Research 43 (Web Server issue), W7-W14. https://doi.org/10.1093/nar/gkv318

Silvestro D, Michalak I (2012) RaxmlGUI: A graphical front-end for RAxML. Organisms Diversity and Evolution 12: 335-337. https://doi.org/10.1007/s13127-011-0056-0

Stamatakis A (2006) RAxML-VI-HPC: maximum likelihood-based phylogenetic analyses with thousands of taxa and mixed models. Bioinformatics 22: 2688-2690. https://doi. org/10.1093/bioinformatics/btl446

Singh KP, Sinha GP (2010) Indian Lichens. An Annotated Checklist. Botanical Survey of India, Ministry of Environment and Forests, M/S Bishen Singh Mahendra pal Singh, Uttarakhand.

Sohrabi M, Sipman H, Toghranegar Z, Nezhadsatari T (2010) A contribution to the lichenized mycota of Zanjan province, Iran. Iranian Journal of Botany 16: 125-129.

Upreti DK, Chatterjee S (1998) Lichen genus Lecanora subgenus Placodium in India. Feddes Repertorium 109: 279-289. https://doi.org/10.1002/fedr.19981090310

Vězda A, Liška J (1999) A catalogue of lichens of the Czech Republic. Institute of Botany, Academy of Sciences of the Czech Republic, Průhonice, 283 pp.

Vondráková OS, Vondrák J (2015) Some new lichen records from the Orenburg Region. Novitates Systematicae Plantarum Non Vascularium 49: 231-238.

White TJ, Bruns TD, Lee S, Taylor J (1990) Amplification and direct sequencing of fungal ribosomal RNA genes for phylogenetics. In: Innis M, Gelfand D, Sninsky J, White T (Eds) PCR Protocols: a Guide to Methods and Applications. Academic Press, New York, 315-322. https://doi.org/10.1016/B978-0-12-372180-8.50042-1

Wirth V (1995) Die Flechten Baden-Württembergs ( $2^{\text {nd }}$ edn), Vol. 1. Eugen Ulmer, Stuttgart, 1006 pp.

Wirtz N, Printzen C, Lumbsch HT (2008). The delimitation of Antarctic and bipolar species of neuropogonoid Usnea (Ascomycota, Lecanorales): a cohesion approach of species recognition for the Usnea perpusilla complex. Mycological Research 112: 472-484. https://doi. org/10.1016/j.mycres.2007.05.006

Zhao X, Leavitt SD, Zhao ZT, Zhang LL, Arup U, Grube M, Pérez-Ortega S, Printzen C, Śliwa L, Kraichak E, Divakar PK, Crespo A, Lumbsch TH (2016) Towards a revised generic classification of lecanoroid lichens (Lecanoraceae, Ascomycota) based on molecular, morphological and chemical evidence. Fungal Diversity 78: 293-304. https://doi.org/10.1007/ s13225-015-0354-5 